JRPIPM. Vol. 2 (2019, no. 2 50-61)

Jurnal Riset Pendidikan dan Inovasi Pembelajaran Matematika

ISSN: 2581-0480 (electronic)

URL: journal.unesa.ac.id/index.php/jrpipm

\title{
Profil Kemampuan Pemecahan Masalah Matematika Siswa SMP pada Materi Peluang Ditinjau dari Gaya Belajar
}

\author{
Niswatul Mufarihah ${ }^{1}$, Rita Yuliastuti ${ }^{2}$, Edy Nurfalah ${ }^{3}$ \\ ${ }^{1}$ Prodi Pendidikan Matematika FKIP Unirow Tuban, niswatulmufarihah@gmail.com \\ ${ }^{2}$ Prodi Pendidikan Matematika FKIP Unirow Tuban, yuliastuti.rita@yahoo.com \\ ${ }^{3}$ Prodi Pendidikan Matematika FKIP Unirow Tuban, masedy@ymail.com
}

\begin{abstract}
ABSTRAK
Penelitian profil kemampuan pemecahan masalah matematika siswa SMP pada materi peluang ditinjau dari gaya belajar bertujuan untuk memperoleh deskripsi kemampuan pemecahan masalah matematika berdasarkan gaya belajar siswa, yaitu gaya belajar visual, auditori, dan kinestetik. Jenis penelitian, deskriptif kualitatif. Subjek penelitian ada 9 siswa, tiap tipe gaya belajar terdiri dari 3 siswa. Hasil penelitian menunjukkan, kemampuan pemecahan masalah matematika siswa dengan tipe gaya belajar visual lebih unggul dibanding siswa dengan tipe gaya belajar auditori maupun kinestetik.

Kata Kunci: kemampuan, pemecahan masalah, gaya belajar .
\end{abstract}

\begin{abstract}
Research on profiles of mathematical problem solving ability in junior high school students on the opportunities material in terms of learning styles aimed to obtain a description of the mathematical problem solving skills based learning styles of students, that learning styles were visual, auditory, and kinesthetic. This type of research was a qualitative descriptive. The subject of research were nine students, each type of learning style consisted of 3 students. The results showed that mathematical problem solving ability of students with the type of visual learning style was superior than the students with the type of auditory and kinesthetic.
\end{abstract}

Keywords: ability, problem solving, learning styles.

\section{Pendahuluan}

Pada sekolah pendidikan dasar dan menengah, siswa belajar matematika disebut matematika sekolah. Salah satu tujuan pembelajaran matematika untuk tingkatan SMP (BSNP, 2006:139), yaitu agar peserta didik memiliki kemampuan memahami konsep matematika, menjelaskan keterkaitan antar konsep dan mengaplikasikan konsep atau algoritma secara luwes,akurat, efisien dan tepat dalam pemecahan masalah. Pentingnya kemampuan siswa dalam pemecahan masalah menurut Barca yang dikutip oleh Syaiful, dkk (2011:216) meliputi: (1) kemampuan pemecahan masalah merupakan tujuan umum 
pengajaran matematika, bahkan sebagai jantungnya matematika; (2) pemecahan masalah meliputi metode, prosedur, dan strategi merupakan proses inti dan utama dalam kurikulum matematika; dan (3) pemecahan masalah merupakan kemampuan dasar dalam belajar matematika. Pemecahan masalah matematika dinilai penting, namun siswa sering mengalami kesulitan dalam memecahkan masalah. Artinya, siswa lebih mempriositaskan hasil akhir dibanding mengutamakan teknik penyelesaian.

Berdasarkan hasil wawancara kepada Bapak Dariyono S.Pd, guru matematika kelas VIII SMP Negeri 5 Tuban menyatakan pada pokok bahasan peluang dengan kompetensi dasar menemukan peluang empirik dan teoritik dari data luaran (output) yang mungkin diperoleh berdasarkan sekelompok data, sebagian besar siswa belum mampu mengaitkan masalah yang dihadapi dengan ilusi kejadian dalam kehidupan nyata, belum mampu memanfaatkan informasi yang diketahui, dan kesulitan dalam menerapkan pengetahuan yang dipelajari sebelumnya sehingga siswa dalam menyelesaikan masalah ke langkah selanjutnya terhenti.

Mengajarkan bahan yang sama, metode yang sama, serta penilaian yang sama kepada semua siswa dianggap akan menghasilkan hasil yang sama adalah anggapan yang kurang tepat. Meskipun semua siswa diperlakukan sama, namun yang melakukan belajar adalah individu-individu itu sendiri, sedangkan kepribadian, emosional, minat dan motivasi siswa tetaplah berbeda. Gaya belajar adalah sebuah pendekatan yang menjelaskan mengenai bagaimana individu belajar atau cara yang ditempuh oleh masingmasing orang untuk berkonsentrasi pada proses, dan menguasai informasi yang sulit dan baru melalui persepsi yang berbeda. Dimana gaya belajar merupakan cara belajar yang unik yang dimiliki setiap individu dalam proses pembelajaran (Ghufron dan Risnawita, 2014:9).

Hasil pengamatan menunjukkan bahwa masih banyak siswa yang mengalami kesulitan atau lamban dalam menangkap pelajaran matematika. Sebagian siswa mencoba mengatasi kesulitan yang dialami dengan meminta teman sebaya yang dianggap lebih faham untuk menjelaskan ulang materi pelajaran yang dibahas atau membaca kembali materi yang telah diajarkan tersebut. Terdapat pula siswa yang sulit memahami materi ketika tidak dituliskan contohnya dipapan tulis sehingga meminta guru untuk memberikan soal sekaligus cara penyelesaiannya. Dari berbagai perbedaan siswa dalam memahami pelajaran yang disampaikan guru dan cara mengatasinya kesulitan belajar menandakan bahwa siswa-siswi memiliki cara yang berbeda-beda. Cara yang siswa gunakan untuk memperoleh dan menyerap informasi yang diajarkan itulah yang disebut gaya belajar.

Berdasarkan preferensi sensori, gaya belajar dapat dibagi dalam tiga kategori. Ketiga kategori tersebut, yaitu gaya belajar visual, auditorial dan kinestetik yang ditandai dengan ciri-ciri perilaku tertentu.

Gaya belajar visual adalah gaya belajar yang lebih banyak memanfaatkan kemampuan "penglihatan”. Menurut DePorter \& Hernacki (2011:116-118), siswa yang bergaya visual biasanya memiliki ciri-ciri: rapi dan teratur; berbicara dengan cepat; perencana dan pengatur jangka panjang yang baik; teliti terhadap detail; mementingkan penampilan baik dalam hal pakaian maupun presentasi; pengeja yang baik dan dapat melihat kata-kata yang sebenarnya dalam pikiran mereka; mengingat apa yang dilihat dari pada yang didengar; mengingat dengan asosiasi visual, biasanya tidak terganggu oleh keributan; mempunyai masalah untuk mengingat intruksi verbal kecuali jika ditulis dan sering kali minta bantuan orang untuk mengulanginya; pembaca cepat dan tekun; lebih suka membaca daripada dibacakan; membutuhkan pandangan dan tujuan yang menyeluruh dan bersikap waspada sebelum secara mental merasa pasti tentang suatu masalah atau proyek; mencoret-coret tanpa arti selama berbicara di telepon dan dalam 
rapat; sering menjawab pertanyaan dengan jawaban singkat ya atau tidak; dan lebih suka melakukan demonstrasi daripada pidato.

Gaya belajar auditori adalah gaya belajar yang lebih banyak memanfaatkan kemampuan "pendengaran". Menurut DePorter \& Hernacki (2011:118), siswa yang bergaya auditori biasanya memiliki ciri-ciri: berbicara kepada diri sendiri saat belajar; mudah terganggu oleh keributan; menggerakkan bibir mereka dan mengucapkan tulisan di buku ketika membaca; senang membaca dengan keras dan mendengarkan; dapat mengulangi kembali dan menirukan nada, mereka kesulitan untuk menulis tetapi hebat dalam berbicara; berbicara dengan irama yang terpola; biasanya pembicara yang fasih; lebih suka musik daripada seni; belajar dengan mendengarkan dan mengingat apa yang didiskusikan daripada yang dilihat; suka berbicara, suka berdiskusi dan menjelaskan segala sesuatu panjang lebar; lebih pandai mengeja dengan keras daripada menuliskannya; dan lebih suka gurauan lisan daripada membaca komik.

Gaya kinestetik adalah gaya belajar yang lebih banyak memanfaatkan kemampuan "fisik". Menurut DePorter \& Hernacki (2011:118-120), siswa yang bergaya visual biasanya memiliki ciri-ciri: berbicara dengan perlahan; menanggapi perhatian fisik; menyentuh orang untuk mendapatkan perhatian mereka; berdiri dekat ketika berbicara dengan orang; selalu berorientasi pada fisik dan banyak bergerak; mempunyai perkembangan awal otot-otot yang besar; belajar melalui memanipulasi dan praktik; menghafal dengan cara berjalan dan melihat; menggunakan jari sebagai penunjuk ketika membaca; banyak menggunakan isyarat tubuh; tidak dapat duduk diam untuk waktu lama; menggunakan kata-kata yang mengandung aksi; menyukai buku-buku yang berorientasi pada plot; mereka mencerminkan aksi dengan gerakan tubuh saat membaca; kemungkinan tulisannya jelek; dan ingin melakukan segala sesuatu.

Huda (2013:287) mengemukakan gaya belajar visual, auditori dan kinestetik (VAK) merupakan gaya belajar multi-sensorik yang merepresentasikan bahwa guru sebaiknya tidak hanya mendorong siswa untuk menggunakan satu modalitas saja, tetapi berusaha mengombinasikan semua modalitas tersebut untuk memberikan kemampuan yang lebih besar dan menutupi kekurangan yang dimiliki masing-masing siswa. Indarto (2012:2) berpendapat bahwa siswa yang mengenali gaya belajarnya sendiri, akan membantu memahami materi yang diberikan guru sehingga siswa mudah memproses materi yang disampaikan guru.

Menurut Siswono (dalam Ilmiyah \& Masriyah, 2013:2), masalah adalah suatu situasi atau pertanyaan yang dihadapi seorang individu atau kelompok ketika mereka tidak mempunyai aturan atau prosedur tertentu yang segera dapat digunakan untuk menentukan jawabannya. Jadi, jika suatu pertanyaan diberikan seseorang dan orang tersebut langsung mengetahui cara mengatasinya dengan benar, maka pertanyaan tersebut tidak bisa dikatakan sebagai masalah. Pemecahan masalah adalah suatu proses yang dilakukan oleh siswa untuk memperoleh penyelesaian masalah matematika dengan menggunakan semua bekal pengetahuan matematika yang dimiliki secara integratif. Tahap pemecahan masalah yang dikemukakan oleh G. Polya (dalam Herlambang, 2013:19-20) antara lain: memahami masalah (understanding the problem), Merencanakan pemecahan masalah (devising a plan), melaksanakan rencana pemecahan masalah (carrying out the plan), dan memeriksa kembali proses dan hasil (looking back).

Adapun tingkat kemampuan siswa dalam memecahkan masalah menurut Departemen Pendidikan Vermont (dalam Nafi'an, 2011:3) ada 3 level yaitu: 1) Levels One: No work is present, or no part of the solution is correct,or Some work is present but the work doesn't support the answer given. 2) Levels Two: The solution is correct for only part of the problem and there is work to support these correct part, or the solution 
contains mathematical error which leads to an incompleteor incorrect answer. 3) Levels Three: The answer is correct and the work the sollution support the answer.

Maksud dari kutipan diatas adalah tingkat kemampuan siswa dalam memecahkan masalah ada 3. Karakteristik kemampuan pemecahan siswa pada tingkat pertama: tidak mengerjakan, tidak sebagaianpun solusi yang diberikan benar, atau beberapa pekerjaan ada, tetapi pekerjaan tidak mendukung jawaban. Karakteristik kemampuan pemecahan siswa pada tingkat kedua: sebagaian benar hanya untuk sebagian masalah dan disana ada pekerjaan untuk mendukung kebenaran sebagian jawaban tersebut, atau solusi mengandung kesalahan perhitungan, yang menyebabkan tidak lengkap atau jawaban tidak benar. Sedangkan karakteristik kemampuan pemecahan siswa pada tingkat ketiga adalah jawaban benar dan semua pekerjaan yang dilakukan untuk memecahkan masalah mendukung jawaban.

Kemampuan pemecahan masalah matematika dalam penelitian ini adalah kecakapan siswa dalam menyelesaikan soal matematika dengan memerhatikan tahapan menentukan apa yang diketahui dan yang ditanyakan, merencanakan proses penyelesaian, mengerjakan rencana hingga diperoleh jawaban, dan memeriksa kembali proses dan hasil yang diperoleh. Selanjutnya dalam penelitian ini akan menggunakan level kemampuan pemecahan masalah menurut Departemen Pendidikan Vermont yang meliputi level 1, level 2, dan level 3 untuk mengukur kemampuan pemecahan masalah siswa.

Berdasarkan uraian diatas, masalah penelitian ini adalah: bagaimana profil siswa SMP yang memiliki gaya belajar tipe visual, auditori dan kinestetik dalam memecahan masalah peluang? Penelitian ini bertujuan untuk memperoleh deskripsi: 1) Profil kemampuan siswa SMP yang bergaya belajar visual dalam pemecahan masalah peluang, 2) Profil kemampuan siswa SMP yang bergaya belajar auditori dalam pemecahan masalah peluang, dan Profil kemampuan siswa SMP yang bergaya belajar kinestetik dalam pemecahan masalah peluang

\section{Metode Penelitian}

Jenis penelitian ini adalah penelitian deskriptif-kualitatif. Lokasi penelitian dikelas VIII SMP Negeri 5 Tuban pada semester II tahun ajaran 2014/2015. Subjek yang dipilih 9 siswa kelas VIII-A dengan cara purposive sampling, masing-masing tiap tipe gaya belajar diambil 3 siswa. Sumber data yang diperoleh dalam penelitian ini ialah data primer yang langsung diambil dari hasil tes pemecahan masalah matematika serta wawancara pada subjek penelitian. Teknik pengumpulan data yang digunakan dalam penelitian ini adalah angket gaya belajar VAK yang diadopsi dari Pertiwi (2015:60-63), tes kemampuan pemecahan masalah, dan pedoman wawancara. Pedoman wawancara ini untuk menggali kemampuan pemecahan masalah peluang yang dilakukan oleh siswa dan disesuai dengan langkah-langkah pemecahan masalah menutut Polya. Adapun tes dan indikator kemampuan pemecahan masalah matematika sebagai berikut.

Kemampuan siswa dalam memahami masalah, merencanakan pemecahan, melakukan rencana pemecahan dan memeriksa kembali pemecahan dilihat dari kecenderungan indikator setiap tahap kemampuan pemecahan masalah yang digunakan siswa dalam memecahkan keseluruhan masalah yang diberikan. Jika indikator level 1 muncul paling banyak maka kemampuan pemecahan masalah subjek termasuk kategori level 1. Jika indikator level 2 muncul paling banyak maka kemampuan pemecahan masalah subjek termasuk kategori level 2. Jika indikator level 3 muncul paling banyak maka kemampuan pemecahan masalah subjek termasuk kategori level 3. Jika indikator level 3, level 2 danatau level 1 terdistribusi sama, maka kemampuan pemecahan masalah subjek dikaterogikan level 2. Karena level tersebut berada dilevel tengah, antara ketidaktahuan dan tahu. 
TABEL 1 Tes Kemampuan Pemecahan Masalah Matematika

\begin{tabular}{ll}
\hline No. & \multicolumn{1}{c}{ Masalah } \\
\hline 1 & Doni dan Dono sedang bermain pelemparan koin. Koin yang digunakan sebanyak 4 buah. \\
& Aturan permainan tersebut yaitu, bila muncul 3 koin bersisi sama dan 1 koin bersisi beda, \\
& maka yang menang adalah Doni. Dan bila muncul 2 angka dan 2 gambar, maka yang menang \\
& adalah Dono. Dari aturan itu, siapakah yang memiliki peluang menang lebih besar dalam \\
& permainan? \\
& Suatu kantong berisi 2 kelereng merah, 3 kelereng putih, dan 5 kelereng biru. Kemudian \\
& diambil sebuah kelereng dari kantong itu. \\
& a. Tentukan peluang terambil kelereng merah. \\
& b. Tentukan peluang terambil kelereng putih. \\
& c. Tentukan peluang terambil kelereng bukan biru (biru komplemen). \\
& Sebuah mata uang dan sebuah dadu dilempar undi sebanyak 100 kali. Tentukan: \\
& a. Peluang munculnya angka pada mata uang dan bilangan prima pada dadu \\
b. Frekuensi harapan pada poin a.
\end{tabular}

TABEL 2 Indikator Kemampuan Pemecahan Masalah Matematika

\begin{tabular}{|c|c|c|}
\hline $\begin{array}{l}\text { Pemecahan } \\
\text { Masalah }\end{array}$ & Level & Indikator \\
\hline \multirow[t]{3}{*}{$\begin{array}{l}\text { Memahami } \\
\text { masalah }\end{array}$} & 3 & $\begin{array}{l}\text { Siswa dapat menentukan apa yang diketahui atau apa yang ditanyakan dengan } \\
\text { lengkap dan tepat }\end{array}$ \\
\hline & 2 & $\begin{array}{l}\text { Siswa dapat menentukan apa yang diketahui atau apa yang ditanyakan sesuai } \\
\text { masalah, namun kurang lengkap dan tepat }\end{array}$ \\
\hline & 1 & Siswa tidak dapat menentukan apa yang diketahui atau apa yang ditanyakan. \\
\hline \multirow[t]{3}{*}{$\begin{array}{l}\text { Merencanakan } \\
\text { pemecahan }\end{array}$} & 3 & $\begin{array}{l}\text { Siswa memiliki rumus memecahkan masalah dan rumus tersebut dapat } \\
\text { membantu dalam menyelesaikan masalah. }\end{array}$ \\
\hline & 2 & $\begin{array}{l}\text { Siswa memiliki rumus memecahkan masalah. Rumus tersebut kurang tepat } \\
\text { dalam membantu menyelesaikan masalah. }\end{array}$ \\
\hline & 1 & Siswa tidak memiliki rumus memecahkan masalah. \\
\hline $\begin{array}{l}\text { Melaksanakan } \\
\text { rencana }\end{array}$ & 3 & $\begin{array}{l}\text { Siswa dapat memecahkan masalah sesuai langkah-langkah pemecahan masalah } \\
\text { yang ia gunakan dengan hasil yang benar. }\end{array}$ \\
\hline \multirow[t]{2}{*}{$\begin{array}{l}\text { pemecahan } \\
\text { masalah }\end{array}$} & 2 & $\begin{array}{l}\text { Siswa kurang dapat memecahkan masalah sesuai langkah-langkah pemecahan } \\
\text { masalah yang ia gunakan dengan hasil yang kurang benar. }\end{array}$ \\
\hline & 1 & $\begin{array}{l}\text { Siswa tidak dapat memecahkan masalah sesuai langkah-langkah pemecahan } \\
\text { masalah yang ia gunakan dengan hasil yang salah. }\end{array}$ \\
\hline \multirow{3}{*}{$\begin{array}{c}\text { Memeriksa } \\
\text { kembali proses } \\
\text { dan hasil }\end{array}$} & 3 & $\begin{array}{l}\text { Siswa melakukan pemeriksaan hasil kebenaran yang diperoleh secara } \\
\text { menyeluruh. }\end{array}$ \\
\hline & 2 & $\begin{array}{l}\text { Siswa melakukan pemeriksaan hasil kebenaran yang diperoleh namun hanya } \\
\text { sebagian. }\end{array}$ \\
\hline & 1 & $\begin{array}{l}\text { Siswa tidak melakukan pemeriksaan hasil kebenaran yang diperoleh dengan } \\
\text { cara yang berbeda ataupun tidak. }\end{array}$ \\
\hline
\end{tabular}

(Nafi'an, 2011:5 dan Nirmalitasari, 2012:6)

Teknik analisis data yang akan digunakan adalah deskriptif naratif dengan menggunakan model Miles dan Huberman yang meliputi reduksi data (data reduction), penyajian data (data display), serta penarikan kesimpulan/verifikasi (conclusion drawing/verification).

\section{Hasil dan Pembahasan}

Berdasarkan hasil angket gaya belajar siswa kelas VIII-A diperoleh potensi gaya belajar visual siswa kelas VIII-A sebesar $31,3 \%$, potensi gaya belajar auditori sebesar $33,7 \%$, dan potensi gaya belajar kinestetik $35 \%$. Sedangkan potensi gaya belajar siswa kelas VIII-A yang lain adalah gaya belajar visual-auditori, visual-kinestetik maupun auditori-kinestetik mempunyai potensi yang sama besar yaitu sebesar 5,56\%. 
Hasil analisis angket gaya belajar, banyak siswa kelas VIII-A yang memiliki gaya belajar auditori. Artinya, siswa belajar harus mendengarkan, menyimak, berbicara, presentasi, berargumentasi maupun menanggapi.Akan membantu sekali, bila guru yang mengajar tersebut dalam berkata diungkapkan dengan suara yang jelas dan lantang. Siswa dengan gaya belajar auditori suka berbicara, suka berdiskusi dan menjelaskan segala sesuatu panjang lebar. Sehingga dapat dikatakan wajar jika suasana kelas VIII-A sangat ramai atau aktif berbicara. Karena 14 siswa kelas VIII-A memiliki potensi gaya belajar auditori.Selain aktif berbicara, siswa kelas VIII-A juga berpotensi aktif bertindak. Karena dilihat dari hasil analisis gaya belajar VAK, 12 orang memiliki gaya belajar kinestetik. Siswa dengan gaya belajar kinestetik memiliki karakteristik selalu berorientasi pada fisik atau banyak gerak dan tidak dapat duduk diam untuk waktu lama.

\subsection{Profil subjek V1, siswa dengan gaya belajar visual}

Berdasarkan pemaparan kemampuan pemecahan masalah nomor 1, 2, dan 3 yang dilakukan subjek V1 bahwa subjek V1 pada tahap memahami masalah dapat menentukan apa yang diketahui atau apa yang ditanyakan dengan lengkap dan tepat, namun tidak ditulis secara eksplisit pada lembar jawaban yang diberikan. Pada tahap merencanakan pemecahan cenderung memiliki rencana pemecahan masalah dan rencana tersebut dapat membantu dalam menyelesaikan masalah, pada tahap melaksanakan rencana pemecahan masalah dapat memecahkan masalah sesuai langkah-langkah pemecahan masalah yang ia gunakan dengan hasil yang benar, dan subjek V1 cenderung melakukan pemeriksaan hasil kebenaran yang diperoleh secara menyeluruh. Hal tersebut dapat dilihat secara ringkas pada tabel 3 .

TABEL 3 Kemampuan Pemecahan Masalah 1, 2 dan 3 pada Subjek V1

\begin{tabular}{lccc}
\hline \multirow{1}{*}{ Tahap } & \multicolumn{3}{c}{ Masalah } \\
\cline { 2 - 4 } & $\mathbf{1}$ & $\mathbf{2}$ & $\mathbf{3}$ \\
\hline Memahami masalah & Level 3 & Level 3 & Level 3 \\
Merencanakan pemecahan & Level 2 & Level 3 & Level 3 \\
Melaksanakan rencana pemecahan & Level 3 & Level 3 & Level 3 \\
Memeriksa kembali proses dan hasil & Level 3 & Level 3 & Level 2 \\
\hline
\end{tabular}

\subsection{Profil subjek V2, siswa dengan gaya belajar visual}

Berdasarkan pemaparan kemampuan pemecahan masalah nomor 1, 2, dan 3 yang dilakukan Subjek V2 bahwa subjek V2 pada tahap memahami masalah cenderung menentukan apa yang diketahui atau apa yang ditanyakan sesuai masalah, namun kurang lengkap dan tepat dan memiliki rencana pemecahanmasalah, namun rencana tersebut kurang tepat dalam membantu menyelesaikan masalah. Adapun pada tahap melaksanakan pemecahan masalah, subjek V2 cenderung kurang dapat memecahkan masalah sesuai langkah-langkah pemecahan masalah yang disebabkan karena ada kesalahan dalam menghitung yang menyebabkan jawaban tersebut tidak benar. Sedangkan pada tahap memeriksa kembali proses, subjek V2 tidak melakukan pemeriksaan hasil kebenaran yang diperoleh. Hal tersebut dapat dilihat secara ringkas pada tabel 4.

TABEL 4 Kemampuan Pemecahan Masalah 1, 2 dan 3 pada Subjek V2

\begin{tabular}{lccc}
\hline \multirow{1}{*}{ Tahap } & \multicolumn{3}{c}{ Masalah } \\
\cline { 2 - 4 } & $\mathbf{1}$ & $\mathbf{2}$ & $\mathbf{3}$ \\
\hline Memahami masalah & Level 3 & Level 2 & Level 2 \\
Merencanakan pemecahan & Level 2 & Level 3 & Level 2 \\
Melaksanakan rencana pemecahan & Level 3 & Level 2 & Level 2 \\
Memeriksa kembali proses dan hasil & Level 1 & Level 1 & Level 1 \\
\hline
\end{tabular}




\subsection{Profil subjek V3, siswa dengan gaya belajar visual}

Berdasarkan pemaparan kemampuan pemecahan masalah nomor 1, 2, dan 3 yang dilakukan Subjek V3 bahwa dalam memahami masalah, subjek V3 cenderung dapat menentukan apa yang diketahui atau apa yang ditanyakan dengan lengkap dan tepat yang tidak ditulis pada lembar jawaban dengan alasan kebiasaan, memiliki rencana pemecahan masalah dan rencana tersebut dapat membantu dalam menyelesaikan masalah dan pada tahap melaksanakan pemecahan masalah, subjek V3 cenderung dapat memecahkan masalah sesuai langkah-langkah pemecahan masalah yang ia gunakan dengan hasil yang benar. Sedangkan pada tahap memeriksa kembali, subjek V3 melakukan pemeriksaan hasil kebenaran yang diperoleh namun hanya sebagian. Hal tersebut, dapat dilihat secara ringkas pada tabel 5 .

TABEL 5 Kemampuan Pemecahan Masalah 1, 2 dan 3 pada Subjek V3

\begin{tabular}{lccc}
\hline \multirow{1}{*}{ Tahap } & \multicolumn{3}{c}{ Masalah } \\
\cline { 2 - 4 } & $\mathbf{1}$ & $\mathbf{2}$ & 3 \\
\hline Memahami masalah & Level 3 & Level 3 & Level 2 \\
Merencanakan pemecahan & Level 3 & Level 3 & Level 3 \\
Melaksanakan rencana pemecahan & Level 3 & Level 3 & Level 2 \\
Memeriksa kembali proses dan hasil & Level 2 & Level 2 & Level 2 \\
\hline
\end{tabular}

\subsection{Profil subjek A1, siswa dengan gaya belajar auditori}

Berdasarkan pemaparan kemampuan pemecahan masalah nomor 1, 2, dan 3 yang dilakukan subjek A1 bahwa subjek A1 memiliki kecenderungan menentukan apa yang diketahui atau apa yang ditanyakan dengan lengkap dan tepat, memiliki rencana pemecahan masalah yang dapat membantu dalam menyelesaikan masalah, dan dapat memecahkan masalah sesuai langkah-langkah pemecahan masalah yang ia gunakan dengan hasil yang benar. Namun pada tahap memeriksa kembali proses dan hasil, subjek cenderung melakukan pemeriksaan hasil kebenaran yang diperoleh namun hanya sebagian. Hal tersebut dapat dilihat secara ringkas pada tabel 6.

TABEL 6 Kemampuan Pemecahan Masalah 1, 2 dan 3 pada Subjek A1

\begin{tabular}{lccc}
\hline \multirow{1}{*}{ Tahap } & \multicolumn{3}{c}{ Masalah } \\
\cline { 2 - 4 } & $\mathbf{1}$ & $\mathbf{2}$ & 3 \\
\hline Memahami masalah & Level 3 & Level 3 & Level 2 \\
Merencanakan pemecahan & Level 3 & Level 3 & Level 2 \\
Melaksanakan rencana pemecahan & Level 3 & Level 3 & Level 1 \\
Memeriksa kembali proses dan hasil & Level 2 & Level 3 & Level 1 \\
\hline
\end{tabular}

\subsection{Profil subjek A2, siswa dengan gaya belajar auditori}

Berdasarkan pemaparan kemampuan pemecahan masalah nomor 1, 2, dan 3 yang dilakukan Subjek A2 bahwa subjek A2 memiliki kecenderungan menentukan apa yang diketahui atau apa yang ditanyakan dengan lengkap dan tepat, memiliki rencana pemecahan masalah yang dapat membantu dalam menyelesaikan masalah, dan dapat memecahkan masalah sesuai langkah-langkah pemecahan masalah yang ia gunakan dengan hasil yang benar. Namun pada tahap memeriksa kembali proses dan hasil, subjek A2 cenderung melakukan pemeriksaan hasil kebenaran yang diperoleh namun hanya sebagian. Hal tersebut dapat dilihat secara ringkas pada tabel 7. 
TABEL 7 Kemampuan Pemecahan Masalah 1, 2 dan 3 pada Subjek A2

\begin{tabular}{lccc}
\hline \multirow{2}{*}{ Tahap } & \multicolumn{3}{c}{ Masalah } \\
\cline { 2 - 4 } & $\mathbf{1}$ & $\mathbf{2}$ & 3 \\
\hline Memahami masalah & Level 3 & Level 3 & Level 2 \\
Merencanakan pemecahan & Level 3 & Level 3 & Level 2 \\
Melaksanakan rencana pemecahan & Level 3 & Level 3 & Level 2 \\
Memeriksa kembali proses dan hasil & Level 3 & Level 2 & Level 2 \\
\hline
\end{tabular}

\subsection{Profil subjek A3, siswa dengan gaya belajar auditori}

Berdasarkan pemaparan kemampuan pemecahan masalah nomor 1, 2, dan 3 yang dilakukan subjek A3 bahwa pada tahap memahami masalah, subjek A3 dapat menentukan apa yang diketahui atau apa yang ditanyakan sesuai masalah, namun kurang lengkap dan tepat. Adapun pada tahap merencankan pemecahan masalah, subjek memiliki kecenderungan memiliki rencana pemecahan masalah yang rencana tersebut kurang tepat dalam membantu menyelesaikan masalah. Pada tahap melaksanakan rencana, kurang dapat memecahkan masalah sesuai langkah-langkah pemecahan masalah yang ia gunakan karena sebagian besar mengandung kesalahan hitung yang menyebabkan hasil yang diperoleh salah. Sedangkan pada tahap memeriksa kembali, subjek A3 tidak melakukan pemeriksaan hasil kebenaran yang diperoleh.Ada beberapa kesalahan yang dilakukan Subjek A3, yang sebenarnya bisa dihindari bilamana melakukan pemeriksaan hasil yang diperoleh. Hal tersebut dapat dilihat secara ringkas pada tabel 8.

TABEL 8 Kemampuan Pemecahan Masalah 1, 2 dan 3 pada Subjek A3

\begin{tabular}{lccc}
\hline \multirow{1}{*}{ Tahap } & \multicolumn{3}{c}{ Masalah } \\
\cline { 2 - 4 } & $\mathbf{1}$ & $\mathbf{2}$ & $\mathbf{3}$ \\
\hline Memahami masalah & Level 2 & Level 2 & Level 2 \\
Merencanakan pemecahan & Level 2 & Level 3 & Level 2 \\
Melaksanakan rencana pemecahan & Level 2 & Level 2 & Level 2 \\
Memeriksa kembali proses dan hasil & Level 1 & Level 1 & Level 1 \\
\hline
\end{tabular}

\subsection{Profil subjek K1, siswa dengan gaya belajar kinestetik}

Berdasarkan pemaparan kemampuan pemecahan masalah nomor 1, 2, dan 3 yang dilakukan subjek K1 bahwa pada tahap memahami masalah, subjek K1 dapat menentukan apa yang diketahui atau apa yang ditanyakan sesuai masalah, namun kurang lengkap dan tepat dan tidak ditulis dalam lembar jawaban dengan alasan kebiasaan. Adapun pada tahap merencanakan, subjek cenderung memiliki rencana pemecahan masalah yang dapat membantu dalam menyelesaikan masalah, namun pada tahap pemecahan kurang dapat memecahkan masalah sesuai langkah-langkah pemecahan masalah yang menyebabkan hasil kurang benar. Sedangkan pada tahap memeriksa kembali, subjek K1 cenderung tidak melakukan pemeriksaan hasil kebenaran yang diperoleh. Hal tersebut dapat dilihat secara ringkas pada tabel 9.

TABEL 9 Kemampuan Pemecahan Masalah 1, 2 dan 3 pada Subjek K1

\begin{tabular}{lccc}
\hline \multirow{2}{*}{ Tahap } & \multicolumn{3}{c}{ Masalah } \\
\cline { 2 - 4 } & $\mathbf{1}$ & $\mathbf{2}$ & $\mathbf{3}$ \\
\hline Memahami masalah & Level 2 & Level 2 & Level 2 \\
Merencanakan pemecahan & Level 3 & Level 3 & Level 2 \\
Melaksanakan rencana pemecahan & Level 3 & Level 2 & Level 1 \\
Memeriksa kembali proses dan hasil & Level 2 & Level 1 & Level 1 \\
\hline
\end{tabular}




\subsection{Profil subjek K2, siswa dengan gaya belajar kinestetik}

Berdasarkan pemaparan kemampuan pemecahan masalah nomor 1, 2, dan 3 yang dilakukan Subjek K2, bahwa pada tahap memahami masalah, subjek K2 cenderung dapat menentukan apa yang diketahui atau apa yang ditanyakan sesuai masalah, namun kurang lengkap dan tepat dan tidak ditulis dalam lembar jawaban dengan alasan kebiasaan. Adapun pada tahap merencanakan, subjek cenderung memiliki rencana pemecahan masalah yang dapat membantu dalam menyelesaikan masalah, namun pada tahap pemecahan tidak dapat memecahkan masalah sesuai langkah-langkah pemecahan masalah yang ia gunakan. Sehingga jawaban yang diperoleh salah. Sedangkan pada tahap memeriksa kembali, subjek K2 cenderung tidak melakukan pemeriksaan hasil kebenaran yang diperoleh. Hal tersebut dapat dilihat secara ringkas pada tabel 10.

TABEL 10 Kemampuan Pemecahan Masalah 1, 2 dan 3 pada Subjek K2

\begin{tabular}{lccc}
\hline \multicolumn{1}{c}{ Tahap } & \multicolumn{3}{c}{ Masalah } \\
\cline { 2 - 4 } & $\mathbf{1}$ & $\mathbf{2}$ & $\mathbf{3}$ \\
\hline Memahami masalah & Level 3 & Level 2 & Level 2 \\
Merencanakan pemecahan & Level 3 & Level 3 & Level 2 \\
Melaksanakan rencana pemecahan & Level 3 & Level 1 & Level 1 \\
Memeriksa kembali proses dan hasil & Level 2 & Level 1 & Level 1 \\
\hline
\end{tabular}

\subsection{Profil subjek K3, siswa dengan gaya belajar kinestetik}

Berdasarkan pemaparan kemampuan pemecahan masalah nomor 1, 2, dan 3 yang dilakukan subjek K3 bahwa pada tahap memahami masalah subjek K3 dapat menentukan apa yang diketahui atau apa yang ditanyakan dengan lengkap dan tepat yang tidak ditulis pada lembar jawaban dengan alasan kebiasaan, cenderung memiliki rencana pemecahan masalah yang dapat membantu dalam menyelesaikan masalah dan pada tahap melaksanakan pemecahan masalah, subjek K3 cenderung dapat memecahkan masalah sesuai langkah-langkah pemecahan masalah yang ia gunakan dengan hasil yang benar. Sedangkan pada tahap memeriksa kembali, subjek K3 memiliki kecenderungan melakukan pemeriksaan hasil kebenaran yang diperoleh namun hanya sebagian. Hal tersebut, dapat dilihat secara ringkas pada tabel 11.

TABEL 11 Kemampuan Pemecahan Masalah 1, 2 dan 3 pada Subjek K3

\begin{tabular}{lccc}
\hline \multirow{1}{*}{ Tahap } & \multicolumn{3}{c}{ Masalah } \\
\cline { 2 - 4 } & $\mathbf{1}$ & $\mathbf{2}$ & $\mathbf{3}$ \\
\hline Memahami masalah & Level 3 & Level 3 & Level 3 \\
Merencanakan pemecahan & Level 3 & Level 3 & Level 2 \\
Melaksanakan rencana pemecahan & Level 3 & Level 3 & Level 1 \\
Memeriksa kembali proses dan hasil & Level 2 & Level 2 & Level 1 \\
\hline
\end{tabular}

\subsection{Profil kemampuan siswa dalam memecahkan masalah matematika ditinjau dari gaya belajar VAK}

Hasil analisis profil kemampuan siswa dalam memecahkan masalah matematika berdasarkan langkah Polya ditinjau dari gaya belajar Visual, Auditori, dan kinestetik dapat dilihat pada tabel berikut.

Tabel 4.12 menunjukkan bahwa kemampuan pemecahan masalah matematika siswa dengan tipe gaya belajar visual lebih unggul dibanding siswa dengan tipe gaya belajar auditori maupun kinestetik. Hasil ini sesuai dengan hasil uji hipotesis yang dilakukan Okki Pramudito (2008), bahwa hanya gaya belajar visual yang memberikan pengaruh yang signifikan terhadap kemampuan memecahkan soal cerita matematika. Adapun kemampuan pemecaahan masalah matematika siswa dengan tipe gaya belajar 
auditori sama dengan siswa dengan tipe gaya belajar kinestetik. Walaupun pada tahap melaksanakan pemecahan masalah sama dilevel 2, namun siswa dengan tipe gaya belajar auditori pada tahap melaksanakan pemecahan masalah lebih unggul. Karena siswa dengan tipe gaya belajar kinestetik pada tahap melaksanakan pemecahan masalah banyak melakukan kesalahan perhitungan, sehingga menyebabkan jawaban tidak benar.

TABEL 12 Profil Kemampuan Siswa dalam Memecahan Masalah Matematika Ditinjau dari Gaya Belajar VAK

\begin{tabular}{lccc}
\hline \multirow{2}{*}{ Tahap } & \multicolumn{3}{c}{ Gaya Belajar } \\
\cline { 2 - 4 } & V & A & K \\
\hline Memahami masalah & Level 3 & Level 2 & Level 2 \\
Merencanakan pemecahan & Level 3 & Level 3 & Level 3 \\
Melaksanakan rencana pemecahan & Level 3 & Level 2 & Level 2 \\
Memeriksa kembali proses dan hasil & Level 2 & Level 1 & Level 1 \\
\hline
\end{tabular}

Meninjau kembali hasil tes dan wawancara pemecahan masalah matematika untuk mengetahui alasan kemampuan siswa dengan gaya belajar visual lebih unggul dalam memecahkan masalah, maka didapat bahwa siswa dengan gaya belajar visual lebih memahami masalah dibanding siswa dengan gaya belajar yang lain. Tanpa adanya pemahaman terhadap masalah yang diberikan, siswa tidak mungkin mampu menyelesaikan masalah tersebut dengan benar.

Alasan lain yaitu, siswa dengan gaya belajar visual lebih teliti. Terkait ketelitian, DePorter \& Hernacki (2011) berpendapat bahwa karakteristik yang dimiliki siswa dengan gaya belajar visual diantaranya adalah teliti terhadap detail. Hal itu, bukan berarti siswa dengan gaya belajar auditori maupun kinestetik tidak teliti dalam memecahkan masalah. Gaya belajar auditori maupun kinestetik juga memiliki ketelitian, hanya saja siswa dengan gaya belajar visual lebih teliti dalam memecahkan masalah terutama pada tahap memahami masalah dan tahap melaksanakan pemecahan masalah. Dengan ketelitian, membuat siswa tipe gaya belajar visual mampu meminimalisir kesalahan perhitungan dan lebih memahami masalah dibanding siswa dengan gaya belajar yang lain.

\section{Kesimpulan}

Hasil penelitian menunjukkan bahwa kemampuan siswa dengan gaya belajar visual pada tahap memahami masalah, merencanakan, dan melaksanakan pemecahan masalah dalam kategori level 3. Sedangkan pada tahap memeriksa kembali proses dan hasil dilevel 2 .

Kemampuan siswa dengan gaya belajar auditori pada tahap memahami masalah berada dilevel 2, merencanakan masalah dalam kategori level 3, melaksanakan rencana dilevel 2, namun pada tahap memeriksa kembali proses dan hasil berada dilevel 1 .

Siswa dengan gaya belajar kinestetik memiliki kemampuan pemecahan masalah, yaitu pada tahap memahami masalah berada dilevel 2, merencanakan masalah dalam kategori level 3, melaksanakan rencana dilevel 2, sedangkan pada tahap memeriksa kembali proses dan hasil berada dilevel 1.

Penelitian yang dilakukan ini masih terdapat kelemahan. Kelemahan tersebut adalah instrumen tes kemampuan pemecahan masalah yang digunakan kurang memenuhi syarat validitas konstruk (tidak terdapat petunjuk secara tertulis bahwa dalam mengerjakan tes kemampuan pemecahan masalah disesuaikan dengan langkah-langkah pemecahan masalah menurut Polya). Sehingga instrumen yang digunakan belum mampu mengukur indikator kemampuan pemecahan masalah yang hendak diukur. Akibat yang ditimbulkan dari ketidakvalidan intrumen tersebut adalah data yang diperoleh kurang 
valid. Hal tersebut berefek pada hasil penarikan kesimpulan penelitian ini yang kemungkinan akan berbeda dengan hasil penarikan kesimpulan dari instrumen yang valid.

Pada langkah memahami masalah, sebaiknya guru membimbing atau membiasakan siswa untuk menulis apasaja yang diketahui dan yang ditanyakan. Dengan membiasakan siswa menulis apa yang diketahui dan yang ditanya, siswa akan belajar mengidentifikasi masalah, fokus pada masalah, membantu dalam memeriksa kembali jawaban, dan belajar berproses, yang tidak hanya mengutamakan hasil.

\section{$5 \quad$ Ucapan Terima Kasih}

Puji syukur panjatkan kehadirat Allah Swt, atas limpahan, rahmat, hidayah dan karunia-Nya sehingga penulis dapat menyelesaikan skripsi dengan judul Profil Kemampuan Pemecahan Masalah Matematika Siswa SMP pada Materi Peluang Ditinjau dari Gaya Belajar Siswa. Terselesaikannya makalah ini tidak terlepas dari bantuan, bimbingan, dan dukungan dari berbagai pihak. Penulis menyampaikan terima kasih kepada: Ibu Dr. Supiana Dian Nurtjahyani, M.Kes, selaku Rektor Universitas PGRI Ronggolawe (UNIROW) Tuban beserta jajarannya yang telah menyediakan berbagai macam fasilitas dan pelayanan, Bapak Dr. H. Djoko Apriono, M.Pd, selaku Dekan FKIP yang telah memberikan dukungannya, Bapak Dr. H. M. Mu'minin, M.Pd, selaku Kepala Lembaga Penelitian yang memberikan ijin pengesahan kepada penulis untuk melakukan penelitian, Bapak Tri Haryanto, S.Pd., M,Pd. Selaku Kepala SMP Negeri 5 Tuban yang telah memberikan waktu dan kesempatan kepada penulis untuk melaksanakan penelitian di sekolah yang dipimpinnya, dan Bapak Dariyono, S.Pd. selaku guru matematika SMP Negeri 5 Tuban yang telah membantu penulis untuk melaksanakan penelitian.

\section{DaftarPustaka}

[1] BSNP. 2006. Standar Isi: Standar Kompetensi dan Kompetensi Dasar SMP/MTs. Jakarta: BSNP.

[2] Syaiful. 2012. Peningkatan Kemampuan Pemecahan Masalah Matematis Melalui Pendekatan Matematika Realistik. Edumatica, (Online), Vol.2 No.1 (http://onlinejournal.unja.ac.id/index.php/edumatica/article/view/603, diakses 11 Juli 2016).

[3] Ghufron, M. Nur dan Rini Risnawita. 2014. Gaya Belajar Kajian Teoritik. Yogyakarta: Pustaka Pelajar.

[4] DePorter, Bobbi dan Mike Henacki. 2011. Quantum Learning: Membiasakan Belajar Nyaman dan Menyenangkan. Bandung: Kaifa.

[5] Huda, Miftahul. 2013. Model-model Pengajaran dan Pembelajaran: Isu-isu Metodis dan Paradigmatis. Yogyakarta: Pustaka pelajar.

[6] Indarto, Danang. 2012. Pengaruh Gaya Belajar Dan Motivasi Berprestasi Siswa Terhadap Prestasi Belajar Praktek Instalasi Listrik Di SMK Negeri 2 Yogyakarta.ePrints@UNY, (Online), (http://eprints.uny.ac.id/2467/, diakses 31 Maret 2016).

[7] Ilmiyah, Sailatul dan Masriyah. 2013. Profil Pemecahan Masalah Matematika Siswa SMP Pada Materi Pecahan Ditinjau dari Gaya Belajar. MATHEdunesa, (Online), Vol.2 No.2, (http://ejournal.unesa.ac.id /index.php/mathedunesa/article/view/1419/, diakses 31 Maret 2016).

[8] Herlambang. 2013. Analisis Kemampuan Pemecahan Masalah Matematika Siswa Kelas VII-A SMP Negeri 1 Kepahiang Tentang Bangun Datar Ditinjau Dari Teori Van Hiele. Tesis Tidak Diterbitkan. Bengkulu: Fakultas Keguruan dan Ilmu Pendidikan Universitas Bengkulu.

[9] Nafi'an, Muhammad Ilham. 2011. Kemampuan Siswa dalam Menyelesaikan Soal Cerita Ditinjau dari Gender di Sekolah Dasar. Makalah Disajikan dalam Seminar 
Nasional Matematika dan Pendidikan Matematika.Jurusan Pendidikan Matematika FMIPA UNY, Yogyakarta, 3 Desember 2011.

[10] Pertiwi.2015. Perbedaan Tingkat Prestasi Belajar Ditinjau dari Kecenderungan Gaya Belajar Siswa Sekolah Dasar.Skripsi Tidak Diterbitkan. Yogyakarta: Fakultas Ilmu Pendidikan Universitas Negeri Yogyakarta.

[11] Nirmalitasari, Okta S. 2012. Profil Kemampuan Siswa dalam Memecahkan Masalah Matematika Berbentuk Open-Start pada Materi Bangun Datar.MATHEdunesa, (Online), Vol.1 No.1, (http://ejournal.unesa.ac.id/index. php/mathedunesa/article/view/247, diakses 15 April 2016).

[12] Pramudito, Okki. 2008. Hubungan Gaya Belajar Siswa dengan Memecahkan Masalah Cerita Matematika bagi Siswa Kelas VIII SLTP 2 Pandak Bantul. Skripsi Tidak Diterbitkan. Yogyakarta: Fakultas Psikologi Universitas Ahmad Dahlan. (Online), Vol.8 No.1 (http://www.eprints.uad.ac.id/skripsi/Psikologi/, diakses 11 Agustus 2016) 